\section{ECONOMICS}

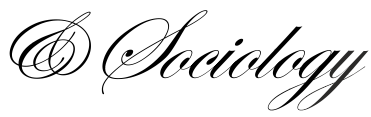

Nguyen V. D., \& Anh, M. N. (2018). Does Governmental Microcrediting Benefit Child Labour in the Poorest Regions? New Evidence from a Transitional Economy. Economics and Sociology, 11(3), 333-344. doi:10.14254/2071-

789X.2018/11-3/20

\title{
DOES GOVERNMENTAL MICROCREDITING BENEFIT CHILD LABOUR IN THE POOREST REGIONS? NEW EVIDENCE FROM A TRANSITIONAL ECONOMY
}

Nguyen Vu Duy,

Department of Tax and Custom, Academy of Finance, Hanoi, Vietnam

E-mail:vunguyent@@yahoo.com, vuduynguyenhvt@@gmail.com

Anh Mai Ngoc, Department of Accounting, Academy of Finance, Hanoi, Vietnam

E-mail:

maingocanbhvt@@gmail.com

Received: March, 2018

1st Revision: April, 2018

Accepted: July, 2018

DOI: $10.14254 / 2071-$

789X.2018/11-3/20

\begin{abstract}
This paper contributes to the literature by examining, for the first time, the influence of credit access on child labour in the poorest regions of Vietnam. Two crucial empirical problems in the linkage between microfinancing and children's labour are considered here the sample selection bias and the endogeneity of microcrediting. Using a combination of the instrumental variable method and the Heckman approach to overcome these problems, the finding is that access to credit decreases the child labour rate. However, when both parametric and nonparametric methods are used, our results show that access to credit only decreases the probability of child labour for households with income per capita greater than 812 thousand VND (approximately 40 USD as of the 2012 rate). These findings imply that policies for relaxation of credit constraints for households may not be effective unless accompanied by the strategies to help households overcome the minimum threshold of income.
\end{abstract}

JEL Classification: O12, I30, Keywords: microcrediting, child labor, ethnic minority, Vietnam. O18.

\section{Introduction}

Child labour is a worldwide phenomenon; however, it is especially painful for the developing world. Many authors offer their theoretical arguments for the relationship between child labour and households' access to credit. On the one hand, some scholars argue that micro-crediting may reduce child labour through improvements in the sources of income, expenditure and healthcare services. On the other hand, the literature has often found a theoretically puzzling positive relationship between microfinancing and child labour. For instance, microcredit may promote the employment of parents. As a result, this may increase 
children labour too because children have to replace their parents in housework, farming and looking after animals as well as in taking care of their younger siblings. These differing impacts of micro-crediting on child labour are discussed in greater detail in the literature review below (see section 2 ).

Evaluating the impact of microcrediting on children's labour faces several empirical challenges. First, sample selection bias means that households may self-select into borrowing activities due to their "better" characteristics. Also, the endogeneity of microcredit is another problem. If studies fail to correct for the problem of self-selection and endogeneity, the estimates will be biased and overstated (Coleman, 2006). Hence, this study goes beyond the literature by using a combination between instrumental variable estimation and the Heckman approach so that to solve the bias in the estimated results.

In addition, while the majority of previous studies consider the linkage between microcrediting and households' welfare in Vietnam, this is the first study to investigate the linkage between micro-crediting and child labour among ethnic minority households (e.g., Tay Thai, Muong, Hmong and Dao) in the North-West Mountains. The literature shows that access to credit may not benefit the poorest, hence, this research focuses on the poorest region of Vietnam to consider whether microcredit programs for the poor really help them. The results are expected to provide solid evidence for policy makers in considering the efficiency of microcredit programs as applied to children welfare.

The paper is structured into four sections. The next section reviews the literature on the impact of micro-crediting on child labour. Section 3 describes data sources and econometric models used in this study. The fourth section presents the empirical results, while the conclusions and policy implications are presented in the final section.

\section{Literature review}

As mentioned above, micro-crediting can impact child labour in two ways. First, access to credit may help households gain higher income because micro-crediting helps their clients diversify sources of income through developing self-employment and increasing work hours (Aghion \& Morduch, 2004; Morduch, 2000). In addition, the access to credit may increase healthcare services of households such as purified drinking water, health insurance, family planning and pregnant-mother care (Littlefield, Morduch, \& Hashemi, 2003). The healthier children may have better school performance, and healthier adults may be more of productive, and then earn more. Conversely, sickness could lead to lose households' income and savings. Furthermore, micro-crediting may smooth household consumption, and reduce the probability of child labour when households faced with adverse shocks (Jacoby \& Skoufias, 1997; Ranjan, 2001).

By contrast, micro-crediting may increase children labour because children have to replace their parents to do housework and farming as well as take care of their younger siblings. In addition, microfinance often has short-term repayment condition and higher interest rates (except preferred loans). Hence, these circumstances may force microfinance borrowers use their own labor including children to reduce their business costs (Chakrabarty, 2015).

In the light of the theoretical perspectives and arguments above, empirical studies on this topic offer mixed findings. For example, Pitt and Khandker (1998) found that girl schooling increased when households borrowed from Gameen Bank. However when households borrowed from other micro-crediting programs, the positive impact of microcrediting on girl schooling was not observed. Similarly, Ersado (2005) in a study for rural Nepal and Zimbabwe indicates that households who access to credit tend to have less child labor. In contrast, Hazarika and Sarangi (2008) in a study on rural Malawi find that children 
tend to work more if their households borrowed. The lack of clarity is a motivation for us to pursue this topic in VietNam.

In Vietnam, a growing literature examining the role of micro-crediting in household welfare is recorded. Several studies show that micro-crediting is an effective tool to improve income and expenditure of households (e.g., Quach, Mullineux, \& Murinde, 2005). Other research reveals that the effect of access to finance on the household welfare is negligible or insignificant (Doan, Gibson, \& Holmes, 2014; Nghiem, Coelli, \& Rao, 2012). However the evidence about the linkage between micro-crediting and child labour is limited. In addition, the evidence of the linkage between micro-crediting and children labour is mixed. For instance, Beegle, Dehejia, and Gatti (2009) show that the households borrowing from lenders with higher interest rates used more child labour in Vietnam. However, another study on Vietnam finds that micro-crediting does not affect child labour (Dinh, Nguyen, \& Pham, 2014).

\section{Methodological approach}

We use the following regression model to estimate the impact of the micro-crediting

$$
\mathrm{Y}_{\mathrm{ij}}=\beta_{0}+\beta_{1} \mathrm{~V}_{\mathrm{ij}}+\beta_{2} \mathrm{X}_{\mathrm{ij}}+\varepsilon_{\mathrm{ij}}
$$

where the dependent variable is represented by labour child of household $\mathrm{i}$ and commune $\mathrm{j}$. The main interest variable $\left(\mathrm{V}_{\mathrm{ij}}\right)$ is the access to credit measured by two variables. First, the micro-crediting is captured by a dummy variable and is equal to 1 if a household borrowed money in the past 4 years from Social Policy Bank or Agricultural and Rural Development Bank; 0 otherwise. ${ }^{1}$ As indicated by Stampini and Davis (2009), the use of a dummy variable allows us to consider the effect of average treatment and minimizes bias due to measurement errors. However, using a dummy variable cannot capture the value of loan. Hence, the amount of loan of a household in the past four years from those two banks and for investment in liquid or fixed assets for production is used as another proxy for the status of credit access of households.

In terms of controlled variables, following the guide by literature (e.g., Doan et al., 2014), household characteristics variables $\left(X_{\mathrm{ij}}\right)$ such as household size, a dummy for language, the area of annual agricultural land, area of perennial agricultural land and area of forest land are also controlled for in the model. Furthermore, the characteristics of household head might have varying effects on the relationship between credit access and child labour (Cuong, 2008; Doan et al., 2014). Consequently, these variables also were controlled for in the model. The statistical descriptions and definitions of variables in the regression analysis are presented in Appendix 2. The $\varepsilon_{\mathrm{ij}}$ is the error term.

In terms of estimation, the endogeneity of explanatory variables is one of empirical challenges when considering the linkage between credit access and child labour. Hence, the methodology of instrumental variable estimation is used to address the endogeneity issue. Using networks as instrumental variable is ad popular approach in the literature (De Brauw \& Harigaya, 2007; Kajisa, 2007; McKenzie \& Rapoport, 2007). Hence, this study also used credit networks as an instrumental variable for credit access. We argue that credit networks play an important role in household's access to credit. This can be explained by the fact that when a household access to credit successfully, it would encourage nearby households to borrow credit for production investment. This channel implies that a household living in a

\footnotetext{
${ }^{1}$ Social Policy Bank and Agricultural and Rural Development Bank are the institutions that implement most microcredit programs for the poor in Vietnam.
} 
community with larger credit networks would has more opportunity of access to credit. Specifically, regressions of equation (1) using survey of 2010 were run. Then, loan networks at the commune level in 2007 as an instrumental variable for the credit variable $\mathrm{V}_{\mathrm{ij}}$ were constructed. The loan networks are the average amount of loan per household at commune level in the past four years (2004, 2005, 2006 and 2007) of the survey of 2007. Obviously, the higher level of loan networks leads to higher probability of credit of households. The firststage equation would be as follows

$$
\mathrm{V}_{\mathrm{ij}}=\alpha_{0}+\alpha_{1} \mathrm{~L}_{\mathrm{j} \_2007}+\alpha_{2} \mathrm{X}_{\mathrm{ijt}}+\alpha_{3} \mathrm{M}_{\mathrm{j}}+\varepsilon_{\mathrm{ij}}
$$

Where $\mathrm{V}_{\mathrm{ij}}$ is the credit variable; $\mathrm{L}_{\mathrm{j} \_2007}$ is loan networks which is constructed in survey of 2007. Specifically, the average loan value per household at commune-level was calculated. This loan amount had occurred in the past four years from Social Policy Bank and Bank for Rural Development and Agriculture and the purpose of this loan had been for investment in liquid or fixed assets for production. $\mathrm{X}_{\mathrm{ij}}$ is a vector of household characteristics variables including household size, productive assets. While $\mathrm{Mj}$ is characteristics of communes, $\varepsilon_{\mathrm{ij}}$ is the error term.

The loan networks have theoretical foundations as an instrument. However, our instrumental variable approach may violate the exclusion restriction. Hence, the Lewbel's method was used to test the exclusion restriction of our instrumental variable (Lewbel, 2012).

There are two stages in the Lewbel's approach. First, a set of exogenous variables, W, where $\mathrm{W} \subset \mathrm{X}$ or even $\mathrm{W}=\mathrm{X}$ is identified. Then, the endogenous variable $\mathrm{V}$ was regressed on exogenous variable $\mathrm{W}$. When the P-value of the Breusch-Pagan / Cook-Weisberg test for heteroscedasticity is statistically significant, an instrumental variable is constructed by using these residuals: $(W-\bar{W}) \hat{v}$. Where $\bar{W}$ is the average of $\mathrm{W}_{\mathrm{i}}$ ( $\mathrm{i}$ is the element of the $\mathrm{W}$ vector), $\hat{v}$ is residual. Second, the regression is estimated by using 2SLS or GMM with $(W-\bar{W}) \hat{v}$ used as an instrumental variable.

Furthermore, the model specifications presented in previous sections may be incorrect due to sample selection bias. In particular, households are poor, so they are eager to obtain access. In addition, the government may want provide more credit to poor communes to improve household welfare. As a result, the effect of credit on child labour may be biased. We conducted two steps to correct for selection bias. First, the Heckman selection model was estimated. Then, the Mill's ratio is added into IV regressions. Specifically the Probit model for securing credit was estimated, and then obtained the linear predictors from the model: p_hat. The Mill's ratio was calculated by $\exp \left(-.5^{*}\right.$ p_hat $\left.{ }^{2}\right) /(\operatorname{sqrt}(2 *$ _pi $) *$ normprob(p_hat $\left.)\right)$. Our main results were re-estimated by adding terms - Mill's ratio - to the regressions.

\section{Conducting research and results}

This study uses two surveys, including Baseline and Endline surveys of Program 135II which were conducted in 2007 and 2012, respectively. The Program 135-II is a Northern Mountains Poverty Reduction Project. The overall objective of the Program 135 is to reduce poverty rates, improve the agricultural productivity of the main crops, and increase the school enrollment rate in the Northern Mountains, Vietnam. Also, the project focus on the development of productive infrastructure in poor areas in this region by providing financial supports for the poor to foster farm and off-farm activities.

The two surveys were conducted by the General Statistical Office of Vietnam with two stages. The first stage of the program was conducted in the period 2001-2005, while second phase of the program was implemented during 2006-2010. The two surveys cover the same sample of 6,000 households living in 400 communes. All of these communes located in 
the areas with the most difficult socio-economic conditions. In addition, nearly76 percent of surveyed households belong to ethnic minority groups. Due to surveys in communes with the most difficult socio-economic conditions, 43 of 63 provinces were included in these two surveys. Those surveys provide a lot of information on characteristics of individuals, households and communes. Furthermore, the most important information on credit of households from various ethnicities such as Tay, Thai, Muong, H'Mong and Dao are available in the datasets.

These surveys include the questionnaires of household and the commune. The household questionnaire collected the detailed information of characteristics of household members, education, employment, healthcare, housing, durables and participation of households into targeted programs are contained in the household data. The commune questionnaires included information about the characteristics of communities such as demography, population, infrastructure, off-farm job opportunities, natural calamities, diseases of domestic animals and crop plants. . Then, the commune data and household-level data are merged to create a unique commune-firm data for this study. Taken together, these surveys can be considered as most comprehensive and the best data source to study ethnic minority groups in Vietnam. ${ }^{2}$

\subsection{Application of multiple linear regression analysis}

This section presents the empirical findings of testing the role of credit access on child labor. First, the validity of instrumental variable is tested. The Appendix 1 reports the firststage result of equation (2) in which access to credit has highly statistically significance with loan networks. The results show that higher level of loan networks leads to higher growth of loan of households or greater probability of households borrowing credit. More specifically, the F- test of excluded instruments is larger than 10, suggesting that our instrumental variable is strong. The results are robust for different models when we add more control variables.

As displayed in Table 1, the results in the equation of child labour in columns (1) and (2) reveal that credit access has a statistically significant negative effect on the number of working days per month of children. The Table 1 reports the results on impact of credit on child labor by using both OLS and instrumental variable regressions. Our results show that access to credit decreases the number of working days per month of children of households. The magnitude of coefficient of access to credit with instrumental variable method is much larger than that with the OLS. The estimated results are still statistically significant when more variables such as agricultural land (Columns 2-3) are controlled for. Specifically, the access to credit decreases child labor by 4.5 days per month, keeping others constant.

It is noted that the credit is measured as a dummy covariate which may not capture the level of the loan. Hence, in a further approach, a continuous variable is used to capture the loan value. Columns 4-6 report that the estimated results are downward biased if without using the instrumental variable method. Specifically, higher loan value reduces number of working days per month of children. These results are in line with the findings of Ersado (2005) who reveals that higher access to microcredit improves the investment in child schooling and reduces the probability of child labour.

\footnotetext{
${ }^{2}$ For more details concerning data conducted in this study, please to see Cuong, Tung, and Westbrook, (2015)
} 
Table 1. The effect of Credit on Child labor

(Dependent variable: number of working days per month of children aged 6-14 in a household)

\begin{tabular}{|c|c|c|c|c|c|c|}
\hline & OLS & IV & IV & OLS & IV & IV \\
\hline & (1) & (2) & (3) & (4) & (5) & (6) \\
\hline Dummy for credit & $\begin{array}{l}-0.447^{* *} \\
(0.211)\end{array}$ & $\begin{array}{c}-4.629^{* *} \\
(1.866)\end{array}$ & $\begin{array}{l}-4.448^{* *} \\
(1.902)\end{array}$ & & & \\
\hline Log (loan value+1) & & & & $\begin{array}{l}-0.048^{* * *} \\
(0.022)\end{array}$ & $\begin{array}{c}-0.465^{* *} \\
(0.187)\end{array}$ & $\begin{array}{c}-0.447^{* *} \\
(0.191)\end{array}$ \\
\hline Household size & $\begin{array}{l}0.703^{* * *} \\
(0.051)\end{array}$ & $\begin{array}{l}0.783^{\text {*** }} \\
(0.061)\end{array}$ & $\begin{array}{l}0.771^{* * *} \\
(0.062)\end{array}$ & $\begin{array}{c}0.703^{\text {*** }} \\
(0.051)\end{array}$ & $\begin{array}{l}0.784^{* * *} \\
(0.061)\end{array}$ & $\begin{array}{l}0.772^{* * *} \\
(0.062)\end{array}$ \\
\hline Dummy for Vietnamese language & $\begin{array}{l}-0.365 \\
(0.252)\end{array}$ & $\begin{array}{l}-0.251 \\
(0.271)\end{array}$ & $\begin{array}{l}-0.222 \\
(0.268)\end{array}$ & $\begin{array}{l}-0.363 \\
(0.252)\end{array}$ & $\begin{array}{l}-0.244 \\
(0.271)\end{array}$ & $\begin{array}{l}-0.215 \\
(0.268)\end{array}$ \\
\hline Age of household head & $\begin{array}{c}-0.030^{* * * *} \\
(0.008)\end{array}$ & $\begin{array}{c}-0.040^{* * * *} \\
(0.009)\end{array}$ & $\begin{array}{c}-0.039^{* * * *} \\
(0.009)\end{array}$ & $\begin{array}{c}-0.030^{* * * *} \\
(0.008)\end{array}$ & $\begin{array}{c}-0.039^{* * * *} \\
(0.009)\end{array}$ & $\begin{array}{r}-0.038^{* * * *} \\
(0.009)\end{array}$ \\
\hline Ethnicity of household head & $\begin{array}{l}-0.007 \\
(0.296)\end{array}$ & $\begin{array}{l}-0.115 \\
(0.302)\end{array}$ & $\begin{array}{l}-0.086 \\
(0.307)\end{array}$ & $\begin{array}{l}-0.006 \\
(0.296)\end{array}$ & $\begin{array}{l}-0.080 \\
(0.299)\end{array}$ & $\begin{array}{l}-0.054 \\
(0.305)\end{array}$ \\
\hline $\begin{array}{l}\text { Household head with upper-school education or } \\
\text { above }\end{array}$ & $\begin{array}{c}-1.732^{* * *} \\
(0.243)\end{array}$ & $\begin{array}{c}-1.643^{* * *} \\
(0.259)\end{array}$ & $\begin{array}{c}-1.605^{* * *} \\
(0.257)\end{array}$ & $\begin{array}{l}-1.729^{* * *} \\
(0.243)\end{array}$ & $\begin{array}{l}-1.629^{* * *} \\
(0.260)\end{array}$ & $\begin{array}{r}-1.592^{* * *} \\
(0.258)\end{array}$ \\
\hline Household head with lower-school education & $\begin{array}{c}-1.579^{* * *} \\
(0.259)\end{array}$ & $\begin{array}{l}-1.420^{* * * *} \\
(0.285)\end{array}$ & $\begin{array}{c}-1.382^{* * * *} \\
(0.283)\end{array}$ & $\begin{array}{l}-1.575^{* * * *} \\
(0.259)\end{array}$ & $\begin{array}{l}-1.385^{* * * *} \\
(0.290)\end{array}$ & $\begin{aligned}-1.349^{* * * *} \\
(0.287)\end{aligned}$ \\
\hline Household head with primary school education & $\begin{array}{c}-1.988^{* * *} \\
(0.376)\end{array}$ & $\begin{array}{l}-1.671^{* * * *} \\
(0.426)\end{array}$ & $\begin{array}{l}-1.624^{* * * *} \\
(0.423)\end{array}$ & $\begin{array}{l}-1.980^{* * *} \\
(0.376)\end{array}$ & $\begin{array}{l}-1.627^{* * *} \\
(0.432)\end{array}$ & $\begin{aligned}-1.582^{* * *} \\
(0.430)\end{aligned}$ \\
\hline Log (annual agricultural land +1 ) & $\begin{array}{c}0.050 \\
(0.044)\end{array}$ & & $\begin{array}{c}0.044 \\
(0.045)\end{array}$ & $\begin{array}{c}0.050 \\
(0.044)\end{array}$ & & $\begin{array}{c}0.043 \\
(0.045)\end{array}$ \\
\hline Log (perennial agricultural land +1 ) & $\begin{array}{l}-0.058 \\
(0.035)\end{array}$ & & $\begin{array}{l}-0.021 \\
(0.041)\end{array}$ & $\begin{array}{l}-0.058 \\
(0.036)\end{array}$ & & $\begin{array}{l}-0.021 \\
(0.040)\end{array}$ \\
\hline $\log ($ forest land +1 ) & $\begin{array}{l}-0.059^{* *} \\
(0.027)\end{array}$ & & $\begin{array}{l}-0.045 \\
(0.029)\end{array}$ & $\begin{array}{l}-0.059^{* *} \\
(0.027)\end{array}$ & & $\begin{array}{l}-0.045 \\
(0.029)\end{array}$ \\
\hline Constant & $\begin{array}{c}0.889 \\
(0.541)\end{array}$ & $\begin{array}{l}2.129^{* * *} \\
(0.669)\end{array}$ & $\begin{array}{l}1.891^{* * * *} \\
(0.732)\end{array}$ & $\begin{array}{c}0.882 \\
(0.542)\end{array}$ & $\begin{array}{l}2.000^{* * * *} \\
(0.632)\end{array}$ & $\begin{array}{l}1.774^{* *} \\
(0.699)\end{array}$ \\
\hline$N$ & 5668 & 5665 & 5665 & 5665 & 5665 & 5665 \\
\hline
\end{tabular}

Notes: Standard errors in parentheses. ${ }^{*} p<0.10,{ }^{* *} p<0.05,{ }^{* * *} p<0.01$.

Regarding controlled variables, Table 1 indicates that larger household size increases child labour. In addition, being able to speak Vietnamese language may be an important factor of increasing income of households but not for child labour. The age of household head is positively correlated with income per capita, suggesting that older household head has more work experience and better income. Hence, this will reduce child labour. As expected, the household head having better level of education also plays a vital role in increasing living standards of households and their child schooling. This can be explained by the fact that the families with more educated parents often have higher income. As a result, this in turn helps households to send children to school instead of keep them working (Doan et al., 2014).

\section{The robustness check}

In Table 2, our main findings are verified by a series of robustness checks. First, our instrumental variable - loan networks - may violate the exclusion restriction. Hence, the instrumental variable $-(W-\bar{W}) \hat{v}$ and loan networks are used as instrumental variables togethor. The P-value of the Sargan statistic is not statistically significant, suggesting that our instrumental variable is valid or overcomes the exclusion restriction. In addition, our estimations may be incorrect due to sample selection bias. Therefore, the Heckman selection model is estimated. Then, the Mill's ratio is added into IV regressions. However, negative effects of microcredit on child labour are still recorded in most cases. 
Table 2. The effect of Credit on Child labor

(Dependent variable: number of working days per month of children aged 6-14 in a household)

\begin{tabular}{lcccc}
\hline VARIABLES & Standard IV & Standard IV & $\begin{array}{c}\text { Standard IV and } \\
\text { Lewbel's intrument }\end{array}$ & $\begin{array}{c}\text { Standard IV and } \\
\text { Lewbel's intrument }\end{array}$ \\
\hline & $(1)$ & $(2)$ & $(3)$ & $(4)$ \\
Dummy for credit & $-4.380^{* *}$ & & $-4.612^{* *}$ & \\
Log (loan value+1) & $(1.918)$ & & $(1.899)$ & \\
& & $-0.440^{* *}$ & & $-0.438^{* *}$ \\
Mills' ratios & 21.452 & $(0.192)$ & & $(0.192)$ \\
& $(25.276)$ & $(25.149)$ & $(25.346)$ & 22.074 \\
Constant & -25.437 & -26.270 & -24.459 & $-26.142)$ \\
& $(32.302)$ & $(32.123)$ & $(32.388)$ & $(32.114)$ \\
Observations & & & & \\
R-squared & 5,665 & 5,665 & 5,665 & 5,665 \\
& 0.012 & 0.017 & 0.005 & 0.018 \\
\hline
\end{tabular}

Notes: Standard errors in parentheses. ${ }^{*} p<0.10,{ }^{* *} p<0.05,{ }^{* * *} p<0.01$. All regressions control for household size, dummy for language, age and ethnicity of household head, dummy for household head completing upperschool education or above, dummy for household head completing lower-school education, dummy for household head completing primary school education, log (annual agricultural land +1$)$, log (perennial agricultural land+1), $\log$ (forest land+1).

\section{Bifurcation Effect of credit on child labor}

Finally, we conducted two steps to consider whether there is non-linear relationship between income per capita and child labor. First, child labor is regressed on characteristics of households including household size, dummy for Vietnamese language, age, ethnicity, education of household head, and land of households. Next, we non-parametrically estimate the relationship between the fitted values of number of working days per month of children aged 6-14 in a household and log of real income per capita.

The Figure 1 indicates that there is an inverted-U shaped relationship between child labor and income per capita. Those findings indicate that at the beginning households need more labor to increase income and maintain the minimum level of living standard. The likelihood of child labor declines with income per capita suggest that the households overcome the minimum level of living standard, they would invest more in their children by sending their children to go to school and reducing child labor. The turning point of log of real income per capita is about 812 thousand VND (approximately 40 USD as of the 2012 rate).

Given the potential findings on an inverted-U shaped relationship between income per capita and child labor, we investigate parametrically whether the effect of credit on child labor is non-linear. We base on the turning point of income per capita that is 812 thousand VND to divide the sample into two sub-samples. 


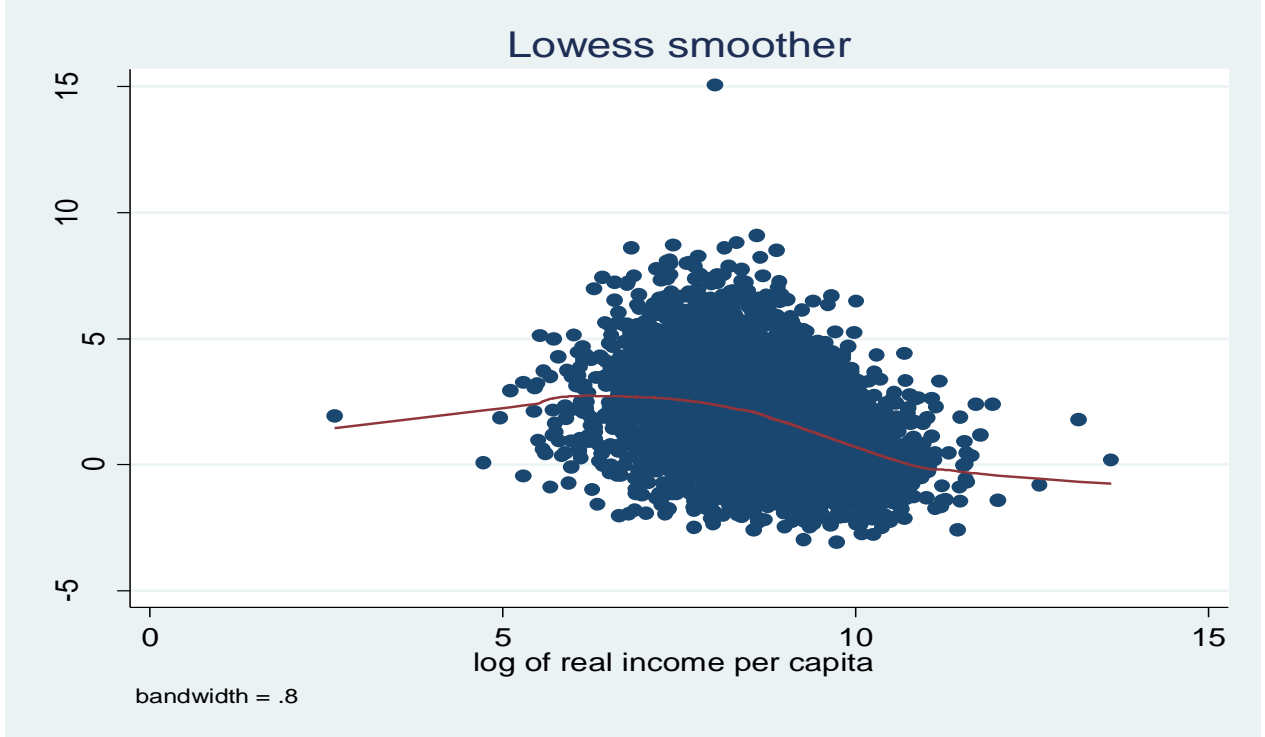

Figure 1. Relationship between child labor and income per capita Notes: Authors' calculations

The bifurcation effect of credit on child labor is presented in Table 3 with instrumental variable method. Table 3 reports the bifurcation effect of credit on child labor. However, there is no evidence on the impact of credit on child labor for the sub-sample of real income per capita less than 812 thousand VND (Columns 1 and 2). However, the negative effect of credit on child labor for the sub-sample of income per capita greater than 812 thousand VND (approximately 40 USD) (columns 3 and 4) is reported. It is noted that the average income per capita in Vietnam is about 130 USD per capita in 2012. Hence, the results imply that microcredit program of the goverment does not help for children of the poorest in the poor group in Vietnam. Hence, in order to reduce child labor and improve their welfares, the government needs to help households overcome the the threshold of 812 thousand VND as a "turning point" of income per capita. This result supports for findings of Chakrabarty (2015), and indicate that the access to credit does not reduce the child labour of extremely poor households.

Table 3. Bifurcation Effect of credit on child labor (Instrumental variable method)

\begin{tabular}{|c|c|c|c|c|}
\hline \multirow[b]{3}{*}{ VARIABLES } & \multicolumn{4}{|c|}{ Child labor } \\
\hline & \multicolumn{2}{|c|}{$\begin{array}{l}\text { Log of real income per capita } \\
\qquad<812,000\end{array}$} & \multicolumn{2}{|c|}{$\begin{array}{l}\text { Log of real income per capita } \\
\qquad 812,000\end{array}$} \\
\hline & IV & IV & IV & IV \\
\hline & (1) & (2) & (3) & (4) \\
\hline Dummy for credit & $\begin{array}{l}-10.947 \\
(12.161)\end{array}$ & & $\begin{aligned}-4.263 * ; \\
(1.931)\end{aligned}$ & \\
\hline $\log ($ loan value +1$)$ & & $\begin{array}{l}-1.077 \\
(1.169)\end{array}$ & & $\begin{array}{c}-0.429^{* *} \\
(0.194)\end{array}$ \\
\hline Observations & 127 & 127 & 5,538 & 5,538 \\
\hline
\end{tabular}

Notes: Standard errors in parentheses. ${ }^{*} p<0.10,{ }^{* *} p<0.05,{ }^{* * *} p<0.01$. All regressions control for household size, dummy for language, age and ethnicity of household head, dummy for household head completing upperschool education or above, dummy for household head completing lower-school education, dummy for household head completing primary school education, log (annual agricultural land+1), log (perennial agricultural land+1), log (forest land+1). 


\section{Conclusion}

This study contributes to the literature by providing the first evidence of the role of credit access on child labour in the poorest of Vietnam. Based on the empirical results from micro-econometric analysis, some main findings may be summarized as follows.

In terms of firm characteristics factors, the empirical results are generally in line with other international empirical studies. For example, having more family members increases child labour. In addition, the education of household head was found to have a significantly reducing the child labour, and the effect increases with the level of education. This suggests that reducing larger family sizes would help alleviate child labour in this region. Family planning measures, among others, have been proved to be a powerful tool in combating poverty in many developing countries (United Nations Population Fund, 2006).

Regarding the connection between credit access and child labour, our endogeneity and sample selection bias-corrected estimates reveal that the credit access has a negative association with child labour. In addition, using both parametric and nonparametric method, our results show that the access to credit only decreases child labour for households with income per capita greater than 812 thousand VND. These findings imply that credit access is likely to be an effective way of reducing child labour problem in the poorest region in Vietnam. However, credit program may only alleviate child labour when it is combined with other supporting programs. For example, an improvement in educational level of household head and simplifying the credit access procedures for the poor ethnic minorities are vital. Taken together, these will help households overcome the minimum threshold of income and promote their children's welfare.

\section{References}

Aghion, B. A. d., \& Morduch, J. (2004). The economics of microfinance. MIT press Cambridge, Massachusetts. Retrieved from http://www.fgda.org/dati/ContentManager/files/Documenti_microfinanza/Economicsof-Microfinance.pdf

Beegle, K., Dehejia, R., \& Gatti, R. (2009). Why should we care about child labor? The education, labor market, and health consequences of child labor. Journal of Human Resources, 44(4), 871-889.

Chakrabarty, S. (2015). A nexus between child labour and microfinance: an empirical investigation. Economic Papers: A journal of applied economics and policy, 34(1-2), 76-91.

Coleman, B. E. (2006). Microfinance in Northeast Thailand: Who benefits and how much? World development, 34(9), 1612-1638.

Cuong, N. V. (2008). Is a governmental microcredit program for the poor really pro-poor? Evidence from Vietnam. The Developing Economies, 46(2), 151-187.

De Brauw, A., \& Harigaya, T. (2007). Seasonal migration and improving living standards in Vietnam. American Journal of Agricultural Economics, 89(2), 430-447.

Dinh, C., Nguyen, C., \& Pham, P. (2014). Does Microcredit Have an Impact on Children? Evidences from Vietnam. Retrieved from https://mpra.ub.uni-muenchen.de/71092/

Doan, T., Gibson, J., \& Holmes, M. (2014). Household credit for the poor and child schooling in peri-urban Vietnam. International Development Planning Review, 36(4), 455-474.

Ersado, L. (2005). Child labor and schooling decisions in urban and rural areas: comparative evidence from Nepal, Peru, and Zimbabwe. World development, 33(3), 455-480.

Hazarika, G., \& Sarangi, S. (2008). Household access to microcredit and child work in rural Malawi. World Development, 36(5), 843-859. 
Jacoby, H. G., \& Skoufias, E. (1997). Risk, financial markets, and human capital in a developing country. The Review of Economic Studies, 64(3), 311-335.

Kajisa, K. (2007). Personal networks and nonagricultural employment: The case of a farming village in the Philippines. Economic Development and Cultural Change, 55(4), 669707.

Lewbel, A. (2012). Using heteroscedasticity to identify and estimate mismeasured and endogenous regressor models. Journal of Business \& Economic Statistics.

Littlefield, E., Morduch, J., \& Hashemi, S. (2003). Is microfinance an effective strategy to reach the Millennium Development Goals? Focus note, 24(2003), 1-11.

McKenzie, D., \& Rapoport, H. (2007). Network effects and the dynamics of migration and inequality: theory and evidence from Mexico. Journal of development Economics, 84(1), 1-24.

Morduch, J. (2000). The microfinance schism. World development, 28(4), 617-629.

Nghiem, S., Coelli, T., \& Rao, P. (2012). Assessing the welfare effects of microfinance in Vietnam: Empirical results from a quasi-experimental survey. Journal of Development studies, 48(5), 619-632.

Pitt, M. M., \& Khandker, S. R. (1998). The impact of group-based credit programs on poor households in Bangladesh: Does the gender of participants matter? Journal of political economy, 106(5), 958-996.

Quach, M., Mullineux, A., \& Murinde, V. (2005). Access to credit and household poverty reduction in rural vietnam: a cross-sectional study. The Birmingham Business School, The University of Birmingham Edgbaston.

Ranjan, P. (2001). Credit constraints and the phenomenon of child labor. Journal of development economics, 64(1), 81-102.

Stampini, M., \& Davis, B. (2009). Does nonagricultural labor relax farmers' credit constraints? Evidence from longitudinal data for Vietnam. Agricultural economics, 40(2), 177-188.

United Nations Population Fund., 2006. Family planning and poverty reduction: benefits for families and nations: The United Nations Population Fund. 


\section{Appendices}

Appendix 1: The results of the first stage regressions

\begin{tabular}{|c|c|c|c|c|}
\hline & \multicolumn{2}{|c|}{$\begin{array}{l}\text { Dependent variable: } \log \\
\quad(\text { loan value }+1)\end{array}$} & \multicolumn{2}{|c|}{$\begin{array}{l}\text { Dependent variable: } \\
\text { Dummy for credit }\end{array}$} \\
\hline & $(1)$ & $(2)$ & (3) & $(4)$ \\
\hline \multirow[t]{2}{*}{ Log (loan networks+1) } & $0.124 * * *$ & $0.123 * * *$ & $0.0124 * * *$ & $0.0123 * * *$ \\
\hline & $(0.0160)$ & $(0.0160)$ & $(0.00166)$ & $(0.00167)$ \\
\hline \multirow[t]{2}{*}{ Household size } & $0.161 * * *$ & $0.160 * * *$ & $0.0161 * * *$ & $0.0159 * * *$ \\
\hline & $(0.0343)$ & $(0.0351)$ & $(0.00362)$ & $(0.00370)$ \\
\hline \multirow{2}{*}{$\begin{array}{l}\text { Dummy for language (equal } 1 \text { for } \\
\text { Vietnamese language, } 0 \text { otherwise) }\end{array}$} & $0.338 *$ & $0.305^{*}$ & $0.0325^{*}$ & 0.0294 \\
\hline & $(0.179)$ & $(0.177)$ & $(0.0189)$ & $(0.0188)$ \\
\hline \multirow[t]{2}{*}{ Age of household head } & $-0.0181 * * *$ & $-0.0186 * * *$ & - & $-0.00211 * * *$ \\
\hline & $(0.00495)$ & $(0.00494)$ & $\begin{array}{c}0.00207 * * * \\
(0.000523)\end{array}$ & $(0.000521)$ \\
\hline \multirow[t]{2}{*}{ Ethnicity of household head } & -0.224 & -0.237 & -0.0313 & -0.0323 \\
\hline & $(0.212)$ & $(0.215)$ & $(0.0219)$ & $(0.0221)$ \\
\hline \multirow{2}{*}{$\begin{array}{l}\text { Household head upper-school education or } \\
\text { above }\end{array}$} & $0.265^{*}$ & 0.224 & 0.0234 & 0.0192 \\
\hline & $(0.156)$ & $(0.156)$ & $(0.0164)$ & $(0.0163)$ \\
\hline Household head lower-school education & $\begin{array}{l}0.451 * * * \\
(0.166)\end{array}$ & $\begin{array}{c}0.403 * * \\
(0.165)\end{array}$ & $\begin{array}{c}0.0381 * * \\
(0.0172)\end{array}$ & $\begin{array}{l}0.0332 * \\
(0.0170)\end{array}$ \\
\hline Household head primary school education & $\begin{array}{c}0.882 * * * \\
(0.268)\end{array}$ & $\begin{array}{c}0.840 * * * \\
(0.268)\end{array}$ & $\begin{array}{c}0.0789 * * * \\
(0.0276)\end{array}$ & $\begin{array}{c}0.0748 * * * \\
(0.0277)\end{array}$ \\
\hline Log (annual agricultural land +1 ) & & $\begin{array}{l}-0.00907 \\
(0.0336)\end{array}$ & & $\begin{array}{l}-0.000525 \\
(0.00346)\end{array}$ \\
\hline Log (perennial agricultural land+1) & & $\begin{array}{c}0.0681 * * \\
(0.0287)\end{array}$ & & $\begin{array}{r}0.00689 * * \\
(0.00303)\end{array}$ \\
\hline $\log ($ forest land +1$)$ & & $\begin{array}{c}0.0247 \\
(0.0238)\end{array}$ & & $\begin{array}{c}0.00258 \\
(0.00249)\end{array}$ \\
\hline Constant & $\begin{array}{c}0.805 * * \\
(0.383)\end{array}$ & $\begin{array}{c}0.938 * * \\
(0.433)\end{array}$ & $\begin{array}{c}0.111 * * * \\
(0.0400)\end{array}$ & $\begin{array}{c}0.122 * * * \\
(0.0451)\end{array}$ \\
\hline$N$ & 5,635 & 5,635 & 5,635 & 5,635 \\
\hline R-squared & 0.039 & 0.041 & 0.036 & 0.038 \\
\hline F- test of excluded instruments & 60.25 & 58.80 & 55.98 & 54.57 \\
\hline
\end{tabular}

Standard errors in parentheses. ${ }^{*} p<0.10,{ }^{* *} p<0.05,{ }^{* * *} p<0.01$ 
Appendix 2. The statistical descriptions of variables in the models

\begin{tabular}{|c|c|c|c|c|}
\hline Variables & Definitions and measurements & Obs & Mean & $\mathrm{Sd}$ \\
\hline \multicolumn{5}{|l|}{ Dependent Variable } \\
\hline Child labour & $\begin{array}{l}\text { Child labor is the total number of working days } \\
\text { per month of children with age 6-14 in a } \\
\text { household. }\end{array}$ & 5,668 & 1.93 & 7.22 \\
\hline $\begin{array}{l}\text { Income per capita } \\
\text { Controlled variables }\end{array}$ & Total income divide by household size & 5,635 & 8.57 & 0.953 \\
\hline Access to credit & $\begin{array}{l}\text { A dummy for credit is equal to } 1 \text { if a household } \\
\text { borrowed money in the past } 4 \text { years from Social } \\
\text { Policy Bank or Agricultural and Rural } \\
\text { Development Bank; } 0 \text { otherwise }\end{array}$ & 5,668 & 0.269 & 0.443 \\
\hline Loan & $\begin{array}{l}\text { The amount of loan of a household in the past } \\
\text { four years from those two banks and for } \\
\text { investment in liquid or fixed assets for } \\
\text { production }\end{array}$ & 5,665 & 2.56 & 4.23 \\
\hline Household size & Total household members (persons) & 5,668 & 4.77 & 1.92 \\
\hline Dummy for language & $\begin{array}{l}\text { A dummy equals } 1 \text { for Vietnamese language, } 0 \\
\text { otherwise }\end{array}$ & 5,668 & 0.345 & 0.47 \\
\hline Age of household head & The age of household head (years) & 5,668 & 45.39 & 12.35 \\
\hline $\begin{array}{l}\text { Ethnicity of household } \\
\text { head }\end{array}$ & The ethnicity of household head & 5,668 & 0.204 & 0.403 \\
\hline $\begin{array}{l}\text { Household head with } \\
\text { upper-school education }\end{array}$ & $\begin{array}{l}\text { Whether or not the household head completed } \\
\text { the upper secondary school or higher level }\end{array}$ & 5,668 & 0.074 & 0.262 \\
\hline $\begin{array}{l}\text { Household head with } \\
\text { lower-school education }\end{array}$ & $\begin{array}{l}\text { Whether or not the household head completed } \\
\text { the lower secondary school }\end{array}$ & 5,668 & 0.195 & 0.396 \\
\hline $\begin{array}{l}\text { Household head with } \\
\text { primary education }\end{array}$ & $\begin{array}{l}\text { Whether or not the household head completed } \\
\text { the primary school }\end{array}$ & 5,668 & 0.221 & 0.415 \\
\hline $\begin{array}{l}\text { Area of annual crop } \\
\text { land }\end{array}$ & $\begin{array}{l}\text { The size of annual crop land size per capita (100 } \\
\mathrm{m}^{2} \text { per person) }\end{array}$ & 5,668 & 6.24 & 2.32 \\
\hline $\begin{array}{l}\text { Area of perennial } \\
\text { agricultural land }\end{array}$ & $\begin{array}{l}\text { The size of perennial crop land size per capita } \\
\left(100 \mathrm{~m}^{2} \text { per person) }\right.\end{array}$ & 5,668 & 1.19 & 2.68 \\
\hline Area of forest land & $\begin{array}{l}\text { The size of forestry land per capita }\left(100 \mathrm{~m}^{2} \text { per }\right. \\
\text { person) }\end{array}$ & 5,668 & 2.02 & 3.44 \\
\hline
\end{tabular}

